Pak. j. sci. ind. res. Ser. B: biol. sci. 201154 (3) 131-135

\title{
High Density Culture of a Cladoceran Moina micrura (Kruz, 1874) by Using Poultry Manure
}

\author{
Mehraj Ud Din War and Kareem Altaff \\ Unit of Reproductive Biology and Live Feed Culture, Department of Zoology, \\ The New College, Chennai-600 014, India
}

(received October 21, 2010; revised March 7, 2011; accepted April 28, 2011)

\begin{abstract}
The branchipod Moina micrura was mass cultured using three different concentrations (250 ppm, $500 \mathrm{ppm}$, and $1000 \mathrm{ppm}$ ) of chicken manure in the medium for 21 days. In the first concentration ( $250 \mathrm{ppm})$, the maximum density $(1694.44 \pm 9.68)$ of $M$. micrura was obtained on the $9^{\text {th }}$ day of inoculation and the number of plankton declined gradually afterwards. In the second concentration (500 ppm), the maximum density $(7296.88 \pm 54.35)$ appeared on the $11^{\text {th }}$ day while in the third concentration $(1000 \mathrm{ppm})$, the maximum density $(1510 \pm 15.27)$ was obtained on the $14^{\text {th }}$ day of inoculation. Temperature range of $27-31^{\circ} \mathrm{C}$ and $\mathrm{pH}$ of 6-7 was conducive for optimal growth of $M$. micrura.
\end{abstract}

Keywords: live feed, Moina micrura, mass culture, poultry manure

\section{Introduction}

Zooplankton is important as food for both young and adult fish (Altaff and Mehraj, 2010; Srivastava et al., 2006; Pangano et al., 2000). Zooplankton collected from natural resources are used as diet for fish and prawn larval rearing in many hatcheries although this is an unreliable source for commercial use according to quality Wild zooplankton may introduce harmful organisms to the hatcheries and hence mass culture under controlled conditions is desirable (Altaff et al., 2002).

M. micrura is a cosmopolitan, cyclic parthenogenetic cladoceran with ample morphological and ecological plasticity, inhabiting temperate, tropical and sub tropical regions worldwide (Martínez-jerónimo et al., 2007). Organic fertilizers are usually preferred on mineral fertilizers because organic fertilizers provide bacterial and fungal cells, detritus as well as phytoplankton as food for Moina (Rottmann et al., 2003). Earlier Jana and Chakrabarthi (1993a) reported the presence of detritus in the gut of M. micrura. Since then different culture techniques have been developed to increase the yield of cladocerans by employing different waste organic products as food sources (Mehraj and Altaff, 2010; Shrivastava et al., 2006; Sivakumar, 2005; Pagano et al., 2000). Among various species of zooplankton, the genus Moina of the Cladocera is known to be suitable as initial feed for larval stages of many fishes. The cost of Artemia cyst is very high and its use in developing

*Author for correspondence; E-mail: kaltaff@rediffmail.com countries may not be appropriate as its production requires some specialized facilities (Hung et al., 1999).

Young Moina are less than $400 \mu \mathrm{m}$ in size, approximately of the same size as that of the adult rotifers and smaller than newly hatched brine shrimps, which die comparatively earlier in freshwater when fed to the fishes. Moina can be stored for longer periods by freezing in low salinity water and can be kept alive for several days in the refrigerator for use as live feed of fish larvae. High temperature tolerance of Moina is also of great advantage for both commercial fish farmers and hobbyists culturing live feed at home. Moina that are cultured in water enriched with organic manures are fed to bigger fish or brooders (Rottmann et al., 2003). Unfortunately, there is little information available concerning practical mass culture methods of $M$. micrura and the literature on tropical and subtropical zooplankton feeding is very scarce (Pangano, 2008). Animal manures like, cattle manure, poultry droppings and agricultural by-products are wastes worldwide and can be used as potential organic manures to increase the productivity of water bodies.

Poultry manure has many advantages for fertilizing culture media when compared to other manures and algae (Altaff and Mehraj, 2010; Shrivastava et al., 2006). Furthermore, the high price of Artemia cysts has increased the fish production cost, therefore cheaper alternative diets with comparable nutritional quality are needed to maintain the competitiveness of ornamental fish on global market (Altaff and Mehraj, 2010; Kumar et al., 2005). 
In this context experiments were carried out on mass culture of M. micrura using poultry excreta, a waste which will make it a cheap and easily available food source to the fish culturists.

\section{Materials and Methods}

Chicken manure was collected from a local broiler chicken shop and was dried for 2 days to remove the moisture and stored in plastic jars for further use. Manure was micronized by grinding and the required quantity was dissolved in distilled water to get suspensions of 250, 500 and $1000 \mathrm{ppm}$ for fertilizing culture medium. Micronisation of poultry waste is necessary for efficient filtration of the suspended particles. Zooplankton samples were collected from Chetpet freshwater pond, Chennai, India and were brought to the laboratory with the least disturbance. The adult M. micrura were identified and separated using binocular dissection microscope based on the key characters outlined by Altaff (2004).

Experimental aquarium tanks of $50 \mathrm{~L}$ capacity arranged in triplicate were filled with $40 \mathrm{~L}$ of filtered water and fertilized with chicken manure at the concentrations of 250, 500 and $1000 \mathrm{ppm}$. After 3 days, M. micrura were inoculated in each experimental tank at the density of $50 \pm 5 \mathrm{Ind} / \mathrm{L}$ containing both adults and neonates. The culture experiment was conducted for 21 days. Water change was carried out at 3 day interval by removing $50 \%$ of the water throughout the culture period. Food was administered as a function of population density every $3^{\text {rd }}$ day using the formula of Altaff and Mehraj (2010):

$\mathrm{Y}=\left[\left(\log 10^{\mathrm{N}} / 10\right)-0.2\right] \times \mathrm{V} \times \mathrm{d}$

where:

$$
\begin{aligned}
\mathrm{Y}= & \text { quantity of chicken manure } \\
\mathrm{N}= & \text { population density }(\mathrm{Ind} / \mathrm{L}) \\
\mathrm{V}= & \text { volume of culture }(\mathrm{L}) \\
\mathrm{d}= & \text { no. of days for which the } \\
& \text { food was administered. }
\end{aligned}
$$

The culture water used in all experiments was filtered tap water, previously aerated for $24 \mathrm{~h}$ to dechlorinate the water. To avoid anaerobic conditions in the medium, the sediments (unconsumed food, faeces, and pseudofaeces) were siphoned out from the bottom three times a week. Excessive fouling was also removed from the walls of the tanks. Wet weight of the animals was determined after draining $10 \mathrm{~L}$ of the culture medium over a nylon gauze of $200 \mu \mathrm{m}$ mesh size and washed several times to remove other debris. The remaining water was absorbed using tissue paper and the animals were weighed on a digital balance with $1 \mu \mathrm{g}$ sensitivity. Population density was estimated by counting samples, taken at random with a $1 \mathrm{~L}$ beaker, after mixing thoroughly the culture volume. Sub-samples of $100 \mathrm{~mL}$ and then $10 \mathrm{~mL}$ were drawn from these samples. Samples were immobilized using alcohol and counting was carried out using Sedgwick Rafter cell under binocular dissection microscope. Results were expressed as number of individuals per litre (Ind/L).

\section{Results and Discussion}

In the first concentration (250 ppm), the peak density $(1694.44 \pm 9.68)$ of $M$. micrura was obtained on the $9^{\text {th }}$ day of inoculation and the number of plankton declined gradually afterwards. In the second concentration (500 ppm), the peak density $(7296.88 \pm 54.35)$ appeared on the $11^{\text {th }}$ day while in the third concentration (1000 ppm) peak density $(1510 \pm 15.27)$ was obtained on the $14^{\text {th }}$ day of inoculation. The lowest density was observed in the tanks fertilized with $1000 \mathrm{ppm}$ concentration (1510 $\pm 15.27)$. Thus the concentration of $500 \mathrm{ppm}$ chicken manure was found to be more suitable for obtaining high density culture of M. micrura than the other concentrations used (Fig. 1). The density (Ind./mL) of protozoan population during different days in the culture medium fertilized with different concentrations of poultry manure is shown in Fig. 2. Higher wet weight of M. micrura biomass ( $\mathrm{mg}$ ) was obtained on the $11^{\text {th }}$ day of the culture (Fig. 3).

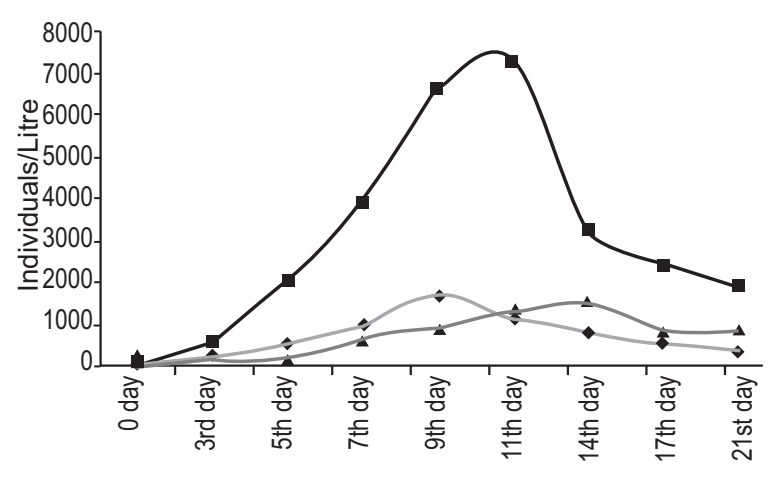

- M.micrura $(250 \mathrm{ppm})-$ M.micrura $(500 \mathrm{ppm})-$ M.micrura $(1000 \mathrm{ppm})$

Fig. 1. Population density of M. micrura $(\mathrm{Ind} / \mathrm{mL})$ during different days in the culture medium fertilized with different concentrations of poultry excreta (Mean $\pm \mathrm{SE}$ ). 


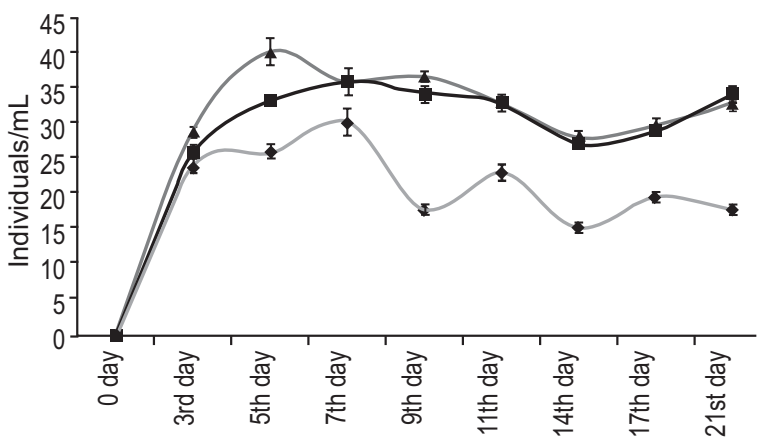

-Protozoan $(250 \mathrm{ppm})-\operatorname{Protozoan}(500 \mathrm{ppm}) \star$ Protozoan (1000ppm)

Fig. 2. Protozoan population density ( $\mathrm{Ind} / \mathrm{mL}$ ) during different days in the culture medium fertilized with different concentrations of poultry manure (Mean $\pm \mathrm{SE})$.

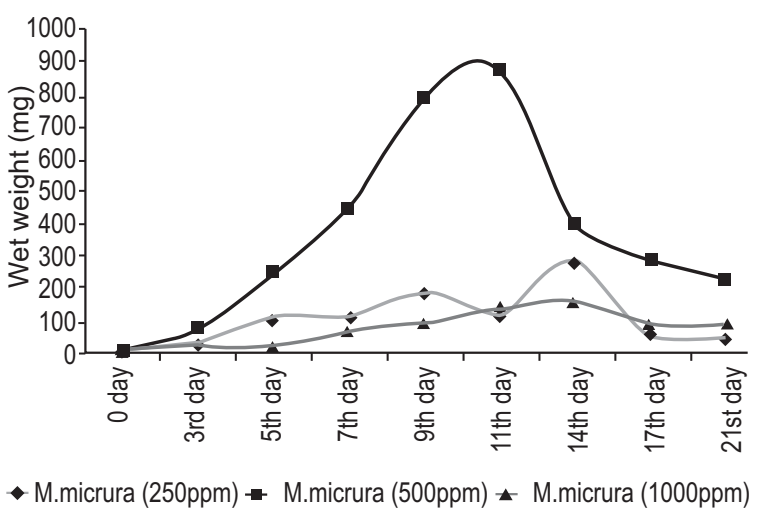

Fig. 3. Wet weight of M. micrura biomass (mg) during different days in the culture medium fertilized with different concentrations of poultry excreta (Mean $\pm \mathrm{SE})$.

In the present experiment, higher production of M. micrura was obtained compared to 1050-2600 Ind/L reported by Punia (1988) and 2500-3500 Ind/L, by Majumdar and Nandy (1989). The dynamic characteristics of zooplankton have led to the use of particular fertilization techniques and species-specific inoculation in culture ponds (Mehraj and Altaff, 2010; Shrivastava et al., 2006). The food supply could be a limiting factor in this type of culture due to high filtering rate. Organic fertilization introduced a complex food web in the fish pond with higher intensity of bacterial activity through the detrital food chain (Safiullah and Altaff, 2002). The nutrients beyond the optimum level reduced population of Moina, which may be due to the rapid degradation of high nutrient content in the medium, resulting in increased production of ammonia and growth of pathogenic microbes resulting in unfavorable conditions for the growth of population (Adeyemo et al., 1994). Boyd and Doyle (1984) Anuta (1992) and reported that high input of chicken manure and commercial feed depressed dissolved oxygen for a prolonged time and water quality deteriorated in the culture resulting in suppressed growth and mortality of the cultured organisms. Similarly, concentration of nutrients below the optimum level also resulted in reduced populations of M. micrura which may be due to insufficient microbial and protozoan populations and lack of sufficient organic compounds, required for the growth and survival of live food organisms. Safiullah and Altaff (2002) also reported higher density of M. micrura at $500 \mathrm{ppm}$ concentration using different nutrient media. Ray and David (1969) opined that chicken manure-fertilized medium produced a large population of cladocerans quicker than cattle manure dosages. The influence of food on the population density of Cladocera has been reported (Srivastava et al., 2006; Jana and Chakrabarthi, 1997; Boersma and Vijverberg, 1996). Usually when environmental conditions are favourable, the progeny is constituted of parthenogenetic females which are clones of mother. When the environmental conditions become unfavorable, sexual reproduction becomes effective, leading to the production of males and females, eventually leading to the formation of resting eggs that enter into diapause, until the conditions become favourable again (Martínez-jerónimo et al., 2007). Gradual decrease after attaining a maximum density may be due to the indirect effects caused by high population densities such as modifying feeding conditions by releasing and accumulating chemical substances or through behavioral indications.

Dissolved oxygen content of the culture medium is another important factor for population growth. In the present study in all culture media, dissolved oxygen level of $4 \pm 1 \mathrm{mg} / \mathrm{L}$ was maintained through aeration and fertilization of the medium. Oxygenation of the medium was assured by air bubbling from the bottom of the culture; aeration also ensured a more regular distribution of the population over the whole volume and prevented stratification (Rottmann et al., 2003). Several authors have stressed that aeration is an important culturing parameter and some studies showed that dissolved oxygen decreased with organic loads of the media (Sivakumar, 2005; Tay et al., 1991). An absolute prerequisite to maintain cultures is to renew parts of the culture water at regular intervals, to ensure permanent good water quality, thereby providing a favourable environment for population growth in higher densities. 
The culture results of Punia (1988) showed a higher density of 1050-2600 Ind/L using ten different raw materials. In the present study a higher density of M. micrura population was recorded compared to previous reports $(7296.88 \pm 54.35)$ on $11^{\text {th }}$ day of culture in tanks fertilized with 500 ppm of chicken manure. Punia (1988) reported that D. lumholtzi in outdoor culture using small containers, produced about 6000 Ind/L. It appears that with proper standardization it is quite possible to culture high density of Cladocera with cheaper organic materials such as agro-industrial waste and manure. Bonou and Saint-Jean (1998) indicated significant correlation in biomass of M. micrura and the initial chlorophyll concentration, which suggests that $M$. micrura population cannot be predicted in the availability of algal food alone.

The physico-chemical parameters appear to play an important role in the successful culture of Cladocera. Tay et al. (1991) did not report any relationship between physico-chemical parameters and physiological processes in zooplankton. Shrigur and Indulkar (1987) had proposed a range of water temperature between 27-31 ${ }^{\circ} \mathrm{C}$ for optimum growth of M. micrura. In the present study, a temperature range of $27-31{ }^{\circ} \mathrm{C}$ produced optimum density of cladocerans. Tay et al. (1991) reported the upper lethal limit close to $40{ }^{\circ} \mathrm{C}$ where $50 \%$ mortality of cladocerans occurred.

Moina micrura can be grown in high densities on optimal quantities of chicken manure. Overfeeding causes high mortality due to unfavorable conditions for culture. This implies that zooplankton with similar feeding modes, can be limited by different factors of their food, which partly explains why so many different organisms are found in the plankton (Hutchinson, 1961). The feeding experiments conducted on M. micrura revealed that the feed concentration plays a decisive role in obtaining the maximum production and this is in accordance with the studies conducted by Safiullah and Altaff (2002); Okauchi (1991) and Yufera et al. (1983). Chicken manure is an excellent food and has many advantages in comparison to other foods, it is available in large quantities; it can be purchased easily at low price; can be used directly after drying; it can be stored for longer periods of time; and it has none of the problems involved in maintenance of algal stocks and cultures. Dried algae are in some cases also an excellent food but they are too expensive to be used at large scale (Altaff and Mehraj, 2010). In the present study high density of M. micrura was obtained, which is commercially viable, especially in the present scenario of organic farming where production of live feed organisms using manures is of considerable importance in order to reduce the cost of seed production and to produce large number of quality seeds. Moreover, the densities obtained at different days at different concentrations are of aquacultural importance, the doses can be manipulated, depending upon the requirement of the aquaculturists.

\section{Acknowledgement}

The authors are thankful to ICAR-NAIP for providing funds to carry out this research work under the project (F.No.1(5)/2007-NAIP dated: 22 August, 2008).

\section{References}

Adeyemo, A.A., Oladosu, G.A., Ayinla, A.O. 1994. Growth and survival of fry of African catfish species, Clarias gariepinus Burchell, Heterobranchus bidorsalis (Geroffey) and Heteroclarias reared on Moina dubia in comparison with other first feed sources. Aquaculture, 119: 41-45.

Altaff, K., Mehraj-Ud-Din, W. 2010. Culture of Ceriodaphnia cornuta, using chicken manure as fertilizer: Conversion of waste product into highly nutritive animal protein. Pakistan Journal of Scientific \& Industrial Research, 53: 89-91.

Altaff, K. 2004. A Manual of Zooplankton. In: Proceedings of National Workshop on Zooplankton from $5^{\text {th }}$ to $10^{\text {th }}$ July 2004, pp. 1-149, sponsored by University Grants Commission, Pakistan.

Altaff, K., Raghunathan, M.B., Suresh Kumar, R., Suriyanarayana, M.M. 2002. Harvest of zooplankton live food for ornamental fishes from natural ponds in north Chennai, Tamilnadu. Indian Hydrobiology, 5: $115-118$.

Anuta, J.D. 1992. Yeilds of Tilapia guineensis in concrete tank receiving manure or a commercial diet. Journal of Aquaculture in the Tropics, 7: 197-204.

Boersma, M., Vijverberg, J. 1996. Food effects on life history traits and seasonal dynamics of Ceriodaphnia pulchella. Freshwater Biology, 35: 25-34.

Bonou, C.A., Saint-Jean, L. 1998. The regulation mechanism and yield of brackish water population of Moina micrura reared in tanks. Aquaculture, 160: 69-79.

Boyd, C.E., Doyle, K.M. 1984. The timing of inorganic fertilization of sunfish ponds. Journal of Aquaculture, 37: 169-177.

Hung, L.T., Tam, B.M., Cacot, P., Lazard, J. 1999. Larval rearing of Mekong catfish, Pangasius 
bocourti (Pangasiidae: Sillurodei): Substitution of Artemia nauplii with live and artificial feed. Aquatic Living Resources, 12: 229-232.

Hutchinson, C.E. 1961. The paradox of the plankton. American Naturalist, 95: 137-145.

Janna, B.B., Chakrabarthi, L. 1997. Effect of manuring rate on in situ production of zooplankton Daphnia carinata. Aquaculture, 156: 85-99.

Janna, B.B., Chakrabarthi, R. 1993a. The effect of management protocols for juvenile carp (Cyprinus carpio) culture on life history responses of zooplankton food source, Moina Micrura (Kruz). Aquaculture, 110: 285-300.

Janna, B.B., Chakrabarthi, R. 1993b. Life table responses of zooplankton (Moina Micrura Kruz and Daphnia carinata King) to manure application in culture system. Aquaculture, 117: 273-285.

Kumar, S., Srivastava, A., Chakrabarti, R. 2005. Study of digestive proteinases and proteinase inhibitors of Daphnia carinata. Aquaculture, 243: 367-372.

Majumdar, S.K., Nandy, A.C. 1989. Experiments on the mass culture of Moina dubia Gurney et Richard. Proceedings of National Seminar Freshwater Aquculture, pp. 93.

Martínez-jerónimo, F., Rodríguez-Estrada, J., VillaseñorCórdova, R. 2007. Effect of culture density and volume on Moina micrura (Kurz, 1874) reproduction and sex ratio in the progeny. Hydrobiologia, 594: 69-73.

Mehraj-Ud-Din, W., Altaff, K. 2010. Culture of Zooplankton for rearing of fish larvae. Pollution Research, 29: 91-93.

Nandy, A.C., Das, P.R., Majumdar, S.K. 1977. Technique to obtain sustained culture of a cladoceran, Daphnia lumholtzi Sars. In: Proceedings of Symposium on Warm Water Zoo-plankton. Special Publication, pp. 540-542.

Okauchi, M. 1991. The status of phytoplankton production in Japan. In: Rotifer and Microalgae Culture Systems, W. Fukka and K. L. Main (eds), pp. 247-256, Proc. US-Asia Workshop, Honolulu, USA.

Omori, K., Oguchi, M., Takeuchi, T. 2006. Development of zooplankton culture subsystem for a closed ecological re-circulating aquaculture system. Acta Astronautica, 58: 82-87.

Pangano, M. 2008. Feeding tropical cladocerans (Moina micrura, Diaphnosoma excisum) and rotifer (Brachionus calyciflorus) on natural phytoplankton: effect of phytoplankton size-structure. Journal of Plankton Research, 30: 401-414.

Pagano, M., Saint-Jean, L., Arfi, R., Boury, M., Sheap,
H. 2000. Population growth capacities and regulatory factors in monospecific culture of the cladoceran Moina micrura and Diaphanosoma excisum and the copepod, Thermocyclops decipiens from cote d' Ivoire (West Africa). Aquatic Living Resources, 13: 163-172.

Punia, P. 1988. Culture of Moina micrura on various organic waste products. Journal of Indian Fisheries Association, 18: 129-134.

Qin, J., Fast, A.W., Kal, A.T. 1997. Tolerance of snakehead Channa stratus to ammonia at different $\mathrm{pH}$. Journal of the World Aquaculture Society, 28: 87-90.

Ray, P., David, A. 1969. Production of cladocerans in different manure. Labdere Journal of Science, 70: 229-231.

Rottmann, R.W., Graves, J.S., Watson, C., Roy, P.E.Y. 2003. Culture techniques of Moina: The ideal Daphnia for feeding freshwater fish fry. CIR 1054/FAO24, pp. 2-9.

Safiullah, A., Altaff, K. 2002. Evaluation of optimium level of different nutrient media for mass production of Moina micrura Kruz. Applied Zoological Research, 13: 90-93.

Shirgur, G.A., Indulkar, S.T. 1987. Continuous mass culture of cladoceran Moina micrura in plastic pool for daily exploitation. Punjab Fisheries Bulletin, 11: 43-48.

Shirugur, G.G., Ingole, B.S. 1983. Further observation on the mass culture of a species of Macrostomia tubrbellarian, Marcrostomum orthostylum (Braun, 1885) under varying salinities and feeding conditions. Proceedings of the National Symposium of Shrimp Seed Production and Hatchery Management, 21-22 January, Cochin (MPEDA) Poster paper, pp. 158.

Shrivastava, A., Rathore, R.M., Chakrabarthi, R. 2006. Effects of four different doses of organic manures in the production of Ceriodaphnia cornuta. Bioresource Technology, 97: 1036-1040.

Sivakumar, K. 2005. Freshwater fish and prawn larval rearing using indigenous live-feed. $P h . D$. Thesis, pp. 1-147, University of Madras, India.

Tay, S.H., Rajbanshi, V.K., Ho, W.H., Chew, J., Yap, E.A. 1991. Culture of cladoceran Moina micrura Kurz using agro industrial waste. In: Proceeding of $4^{\text {th }}$ Asian Fish Nutrition Workshop, S. S. De Silva (ed.), Vol. 5, 1205 pp., Manila, Phillipines.

Yufera, M., Lubian, L.M., Pascula, E. 1983. Effect de cautro algas marinas sobre de cercimiento poblacional de dos cepas de Branchionus plicatilis (Rotifera: Branchionidae) en cultivo. Investigacion Pesquera, 48: 549-556. 